\title{
Dominique Bouchet
}

University of Southern Denmark

ORCID: 0000-0002-1720-9279

DOI: https://doi.org/10.21697/ucs.2020.26.2.03

\section{O KONTEKŚCIE NARODZIN ASTERIXA I ZNACZENIU RELACJI MIĘDZY HISTORIĄ INDYWIDUALNĄ I SPOŁECZNĄ}

\author{
About the context of Asterix's origin and the meaning of the relationship between individual \\ and social history
}

\begin{abstract}
Streszczenie
W artykule zwrócono uwagę na socjologiczny kontekst stworzenia jednej z najbardziej znanych postaci rysunkowych - Gala Asterixa. Przedstawiono pochodzenie jego autorów oraz ich prace, będące wyrazem ich drogi życiowej, podejmowanych decyzji oraz światopoglądu. Ważne znaczenie ma tutaj zagadnienie migracji oraz nawiązywania do własnych losów. Losy twórcy Asterixa są zatem pewnego rodzaju przykładem na bogactwo i złożoność kultur, które finalnie mogą przynieść bardzo dobre rezultaty w tworzeniu dzieł uniwersalnych, zrozumiałych dla każdego i cieszących się wielką popularnością. Gal Asterix jest wykreowaną postacią, która odniosła sukces w kulturze masowej, zatem niezwykle ważne są próby wyjaśnienia jej fenomenu, właśnie poprzez analizę życia i relacji społecznych jego twórcy.
\end{abstract}

Słowa kluczowe: Asterix, komiks, zmiana społeczna, kino, kontekst, kultura, kultura masowa, różnice kulturowe, emigracja, Goscinny, mass media, migracja, segmentacja, socjalizacja

\begin{abstract}
The article highlights the sociological context of creating one of the most famous cartoon characters - Asterix the Gaul. The authors' origins and their creative works are presented, embodying their life path, decisions and worldview. The issue of migration and relating to one's own biographical fate is of great importance here. The fate of the creator of Asterix is therefore a kind of example of the richness and complexity of cultures that can ultimately bring very good results in creating universal works, understandable to everyone and enjoying great popularity. Asterix the Gaul is an invented character who has been successful in mass culture, so it is extremely important to try to explain its phenomenon by analyzing the life and social relations of its creator.
\end{abstract}

Keywords: Asterix, comic book, social change, cinema, context, culture, mass culture, cultural differences, emigration, Gosinny, mass media, migration, segmentation, socialization

\section{Wprowadzenie}

Komiksy o przygodach Asterixa, których akcja rozgrywa się zawsze w latach 50. p.n.e. w okupowanej przez Rzymian Galii, są fenomenem na rynku światowym. Ponad 380 milionów egzemplarzy sprzedanych na całym świecie i przetłumaczonych na 111 języków. Ponadto stały się one inspiracją dla kilkunastu filmów i seriali animowanych. Za każdym razem, gdy ukazuje się nowy album, wielu czytelników cieszy się, że może śmiać się z ulubionych gagów, a dziennikarze próbują odnaleźć związek z bieżącymi wydarzeniami. 
Czy zatem nie powinniśmy się przyjrzeć czynnikom, które spowodowały, że albumy o Asterixie pojawiły się na rynku światowym? Skąd wywodzi się Asterix? W analizie zwrócimy uwagę na historyczne i społeczno-geograficzne, osobiste i zbiorowe, lokalne i globalne ramy, w których ewoluował i działał jego pierwotny twórca René Goscinny' (1926-1977).

Każdy autor należy do swojej epoki, jednak kultura, która go inspiruje, nie należy do nikogo konkretnego. Nikt nigdy nie jest całkowicie zakorzeniony jedynie w swojej rodzimej kulturze, ponieważ zawsze poddany jest wpływom kulturowym swoich czasów, doświadczeniom z własnych podróży i ewolucji warunków życia. Jak zobaczymy, René Goscinny był pod mocnym wpływem swoich osobistych migracji oraz przemian społeczno-kulturowych swojej epoki. Do tych ostatnich sam się przyczynił przez wprowadzenie specyficznego typu komiksu: takiego, który można odczytać na dwóch poziomach. Tam, gdzie dzieci nie dostrzegają niczego poza akcją, dorośli bawią się aluzjami, czytelnymi tylko dla tych, którzy mają wiedzę niezbędną do ich zrozumienia.

\section{O twórczej migracji autora}

René Goscinny urodził się w Paryżu 14 sierpnia 1926 roku² $^{2}$ Pochodził z aszkenazyjskiej rodziny żydowskiej wywodzącej się z Polski i Ukrainy. Jego rodzice otrzymali obywatelstwo francuskie kilka dni przed narodzinami René. Matka, Anna Bereśniak, urodzona w Chodorkowie (Khodoriv), pochodziła z rodziny wydawców. Dziadek ze strony matki, autor pierwszego słownika jidisz-hebrajskiego, mieszkał w Paryżu od 1912 roku i wydawał gazety w języku jidisz oraz rosyjskim. Ojciec René, Stanisław Gościnny, urodzony w Warszawie, przyjechał do Paryża dwadzieścia lat wcześniej, aby studiować chemię stosowaną ${ }^{3}$. Dwa lata po narodzinach René, jego rodzice wraz z dziećmi wyjechali do Buenos Aires. Spędzili tam 17 lat. Tak jak jego brat, René ukończył szkołę podstawową i średnią we francuskich szkołach w stolicy Argentyny. Letnie wakacje spędzał w Urugwaju, gdzie konno przemierzał pampę razem z gaucho. Często razem z rodziną wyruszali w rejsy transantlantyckie, aby odwiedzić dziadków i kuzynów we Francji. Te miłe chwile przeżyte w okresie dzieciństwa, bardzo silny i szczególny związek z Francją, gdzie spędzał piękne i niezapomniane wakacje, nie pozostaną bez wpływu na jego dalsze życie. Bardzo wcześnie zaczął rysować. Póżniej wyjaśniał: „Chciałem rozweselać innych i nie wiedziałem za bardzo, jak to zrobić (...). Ponieważ lubiłem rysować, wydawało mi się, że rysowanie jest najbardziej oczywistym sposobem”. Jego pierwsze prace pojawiły się w biuletynach francuskiego gimnazjum: „Notre voix” i „Quartier latin”. Inspirowały go ilustrowane historie, takie jak Zig i Puce ${ }^{4}$, Tarzan, a zwłaszcza Les Pieds Nickelés ${ }^{5}$, którego album przywieziony z Paryża skrupulatnie skopiował. Jako dziecko René uwielbiał filmy Laurel et Hardy, a także czerpał radość z rozśmieszania kolegów z klasy. W swojej książce wspomina: „Jak byłem mały, robiłem grymasy, robiłem z siebie klauna, rysowałem

1 Uwaga autora nadesłana do redakcji UCS: Ponieważ „goscinny” znaczy po polsku „gościnny”, a autor Asterixa nazywa się Goscinny, to czy nie można by nadać takiego tytułu mojemu wkładowi? (fr.: Puisque "gościnny» signifie «hospitalier » en polonais et que l'auteur d'Astérix s'appelle Goscinny, ne pourrait-on pas donner ce titre à ma contribution?).

2 Głównym źródłem moich informacji o Goscinnym jest 307-stronnicowa biografia napisana z prywatnych archiwów René Goscinnego przez znanego francuskiego historyka Pascala Ory: Ory, Pascal (Ed.). 1987. Goscinny. La liberté d'en rire. Paris: Perrin. Jest również kilka opublikowanych wywiadów z nim, w tym z Numą Sadulem w 1973 roku. Goscinny, René. 2019. „Entretien. Propos recueillis en août 1973 par Numa Sadoul.” Pp. 36-41 in Astérix le gaulois. La naissance d'un mythe, edited by Nicolas Tellop. Paris: Les Cahiers de la BD. Ponadto jest sporo dokumentów cyfrowych dostępnych na stronach internetowych gazet i czasopism, a także programów telewizyjnych.

3 „Stolica Francji przyciąga: 80 proc. Żydów przybyłych z Europy Środkowo-Wschodniej pod koniec XIX wieku w celu osiedlenia się", Temine, Émile. 1999. France, terre d’immigration. Paris: Gallimard (Collection Découvertes Numéro 380).

4 Seria Zig et Puce, przedstawiająca dwóch młodych chłopców podróżujących po świecie w poszukiwaniu fortuny, została opublikowana w 1925 roku. Jej autor Alain Saint-Ogan jest pierwszym francuskim autorem, który podjął się wznowienia elementów amerykańskich komiksów zapoczątkowanych w 1896 roku (zobacz, co piszę dalej także o Yellow Kid), takich jak sekwencyjność obrazów, przenoszenie postaci z jednej sekwencji do drugiej oraz systematyczne stosowanie dymków do przypisania słów lub myśli postaci. Podobnie jak w Stanach Zjednoczonych, swoje pierwsze humorystyczne rysunki publikował w prasie codziennej i w tygodnikach.

5 Jak świadczą na przykład serie Louisa Fortona we Francji: seria Celle des Pieds nickelés opublikowana w 1908 r., a seria BibiFricotin od 1924 r. 
karykatury. Zawsze sprawiałem problemy nauczycielom, choć w sumie byłem dobrym uczniem. (...) Moją pasją było rozśmieszanie innych. To było błaznowanie. W wieku, kiedy dzieci chcą być pilotami czy strażakami, ja chciałem rozśmieszać. Kiedy byłem mały, byłem żartownisiem w pełni tego słowa znaczeniu. To było zajęcie, które musiałem wykonywać bez przerwy" (Goscinny 2014).

Jako nastolatek czarował dowcipem. Jednak na początku drugiej wojny światowej część jego rodziny, która pozostała we Francji, przepadła w obozach koncentracyjnych. René rysował karykatury Hitlera i Mussoliniego, pragnął wrócić do Francji, aby dołączyć do Wolnej Francji. Z żalem napisał w książce, że gdyby wszyscy się śmiali z Adolfa Hitlera, być może ocaliliłoby to miliony istnień ludzkich: „Gdyby widziano Hitlera w groteskowym świetle, małego nerwowego faceta gadającego bzdury, gdyby ludzie wokół niego się śmiali, zamiast traktować go poważnie, mogłoby to uratować kilka milionów istnień luddzkich” (Goscinny 2014). Pomysł Gościnnego można porównać w pewnym stopniu do tego, co próbował trochę później (1940) robić Charlie Chaplin w swoim dziele Dyktator (tytuł orginalny: The Great Dictator). Pierwsze rysunki Goscinnego były publikowane w szkolnych biuletynach francuskigo gimnazjum w Buenos Aires. W 1943 roku, gdy miał 17 lat i rozważał dołączenie do generała De Gaulle’a, nagła śmierć ojca spowodowała, że jego rodzina popadła w biedę, co zmusiło René do przerwania studiów. Talent rysownika pozwolił mu na zatrudnienie się w agnecji reklamowej. W 1945 roku razem z matką opuścił Argentynę, aby dołączyć do swojego wuja w Nowym Jorku. Tak później wspominał decyzję o migracji do Stanów: „Miałem wujka w Stanach Zjednoczonych, który w dość lekki sposób napisał do mnie, mówiąc: Stany Zjednoczone to kraj możliwości etc. I w ten sposób opuściłem Argentynę, w 1945 roku, i przybyłem do Nowego Jorku, gdzie nikt na mnie nie czekał... poza wojskem, które mnie od razu zwerbowało!" (Goscinny 2019: 36-41). Został tłumaczem w marokańskiej firmie importowo-eksportowej. Później wyjechał, aby odbyć służbę wojskową we Francji. Według niektórych źródeł Goscinny miał nadzieję poznać w Ameryce Walta Disneya. „Przyczyną dla której Goscinny po II wojnie światowej zainstalował się w Stanach Zjednoczonych, jeśli wierzyć słynnym słowom scenarzysty: Wyjechatem do Stanów Zjednoczonych aby pracować razem $z$ Waltem Disneyem, ale Walt Disney nic o tym nie wiedzial' (Tellop 2019: 16-23). Po powrocie do Nowego Jorku próbował znaleźć pracę, w której mógłby robić to, co najbardziej lubił: rozśmieszać innych. Niestety nie udało mu się to. Wszystko potoczyło się źle, głodował, był wyzyskiwany i przez półtora roku nie miał pracy. W 1949 roku, podczas pracy w agencji reklamowej, Gościnny poznał Harveya Kurtzmana (1924-1993). „W 1948 roku znowu zostałem rysownikiem, w studio, w którym pracowali Harvey Kurtzman, Will Elder, John Severin, etc., którzy później stworzyli słynnego "Mada«. Ale ja ich znałem jeszcze przed »Madem» i pracowaliśmy razem w Nowym Jorku przy książkach dla dzieci, reklamie i tym podobnych pracach... Potem zostałem dyrektorem artystycznym w wydawnictwie książek dla dzieci. Ten wydawca zbankrutował, a ja odkryłem, że po siedmiu latach w Ameryce zaczyna mi się układać" (Goscinny 2019: 36-41). Harvey Kurtzman kilka lat później, w sierpniu 1952 roku, założył amerykański magazyn parodystyczny „Mad Magazine”, który w pierwszej wersji był komiksem6. W 1950 roku Goscinny wydał swoją pierwszą dwunastostronnicową książkę pop-up book dla dzieci, zawierającą między innymi nową wersję Pinokia.

Podczas powrotu z wakacji spędzonych w Paryżu Goscinny poznał na statku francuskiego eksportera sera, który przedstawił go belgijskim autorom kreskówek, mieszkającym w USA. Wśród nich był Joseph Gillain alias Jijé (1914-1980), który podczas wojny przejął postać Spirou i osiadł w Connecticut. Jijé dostrzegł, że Gościnny ma mniejszy talent do rysowania niż jego poprzedni dwaj uczniowie - Franquin (1924-1997) (który później - w 1957 roku - zostanie wspaniałym autorem antybohatera Gastona Lagaffe’a, a który dopiero co w belgijskiej gazecie „Spirou” przejął porzuconą przez swojego mentora gwaizdorską serię Spirou et Fantasio) oraz Morris (który właśnie stworzył postać Lucky Luke’a). Jijé zauważył też, że Goscinny ma niesamowity

6 Mad będzie książką komiksową od 1952 do 1955 roku (23 numery), zanim stanie się czasopismem. Podbił studencką publiczność, oddając się satyrze mediów i wartości amerykańskiego społecześnstwa, parodiując wszystko/bez ograniczeń klasykę literatury czy komiksy, a także ówczesne hollywoodzkie przeboje.

7 Komiks i postać Spirou zostały stworzone przez francuskiego rysownika François Roberta Veltera, znanego pod pseudonimem Rob-Vel. Po raz pierwszy został opublikowany przez Wydawnictwo Dupuis w „Le Journal de Spirou” („Magazyn Spirou”) 21 kwietnia 1938 r. Na początku II wojny światowej Velter przyłączył się do działań wojennych. Postać Spirou odkupił od niego wydawca i przekazał kolejnym rysownikom. Pierwszym z nich był w 1943 r. właśnie Jospeh Gillain (przyp. tłumacza). 
zmysł do gagów i kalamburów, którego wówczas często brakowało europejskim autorom komiksów. W rezultacie Morris poprosił Goscinnego o napisanie scenariusza do Lucky Lukéa, a ten stanie się „człowiekiem, który szybciej strzela niż jego cień”. Pierwsza przygoda napisana przez Goscinnego pojawiła się w „Spirou” w 1955 roku. Po powrocie do Paryża Goscinny porzucił rysowanie, aby całkowicie poświęcić się pisaniu. Został scenarzystą.

Interwencja Goscinnego przyniosła ewolucję w przygodach Lucky Luke’a. Obaj autorzy dobrze znali folklor Dzikiego Zachodu. Będą drwić z postaci historycznych: Calamity Jane, Jesse Jamesa, Billy’ego the Kida, sędziego Roya Beana. Będą parodiować western. W latach 1957-1977 Goscinny napisze scenariusze 36 przygód Lucky Lukéa.

Po powrocie do Francji w 1951 r. Goscinnemu powierzono odpowiedzialność za paryski oddział małej brukselskiej agencji prasowej World Press, której właściela poznał wcześniej w Nowym Jorku: „W Nowym Jorku w 1940 roku poznałem także wydawcę Dupuis, a także Georgesa Troisfontainesa, który miał małą agencję w Brukseli, La World Press, i dostarczał materiały dla Dupois. Troisfontaines powiedział mi, żebym przyjechał do niego do Brukseli" (Goscinny 2019). Georges Troisfontaines marzył o agencji prasowej, która miałaby zapewnić belgijskiej prasie zaplecze redakcyjne i rysunkowe wspierające realizację strategii reklamowych . Tam poznał Alberto Uderzo ${ }^{8}$ (1927-2020). Spotkanie, podobnie jak to z Morrisem w USA, pozwoliło mu zrozumieć korzyści płynące z wymiany pomiędzy autorem tekstów a „reżyserem obrazów”. Goscinny zapoznał Uderzo z produkcjami amerykańskich rysowników: Harveya Kurtzmana, Jacka Davisa, Walta Kelly’ego i Willa Eidera, których poznał w Nowym Jorku. Zauroczeni duchem amerykańskiej gazety „Mad”, obaj autorzy chcieli wyprowadzić komiks z literatury dziecięcej i stworzyć komiks adresowany zarówno do nastolatków, jak i do dorosłych. Razem, w latach 1952-1958, stworzyli serię w nowym komicznym stylu, pełną odniesień międzykulturowych (Jehan Pistolet, Luc Junior i Oumpah-Pah, powstałych odpowiednio w 1952, 1954 i 1958 roku). Te odniesienia międzykultuorowe oraz nasycenie literatury dziecięcej komiksami staną się przełomową nowością, która pozwoli na rozwinięcie nowego produktu na nowym rynku.

I tak, po przeżyciu 17 lat w Argentynie i 7 lat w Nowym Jorku, Goscinny znalazł się w Europie. Warto zaznaczyć, że przed powrotem do Paryża, gdzie się urodził, zanurzył się niejako w trzech kulturach: Buenos Aires, Nowego Jorku i Brukseli. Kilka lat później w wywiadzie dla „Paris Match” powiedział: „Bardzo lubiłem obcokrajowców; sam przez długi czas byłem obcokrajowcem” (Ory 1987). Goscinnemu zawsze towarzyszyło wyobrażenie jego osobistej historii, naznaczonej między innymi przez doświadczenia szkolne z gimnazjum francuskiego oraz Holocaust, którego doświadczyła jego rodzina. Należy jednak zaznaczyć, że istotny był równeż czas prób i trudnych doświadczeń młodego rysownika w powojennym Nowym Jorku, ponieważ ten okres był fundamentalnym krokiem, który pozwolił na zakiełkowanie/pojawienie się w jego wyobraźni zaczynu tego co globalne i tego co lokalne w jego późniejszych dziełach. W Argentynie Goscinny żył filmami. Był pasjonatem kina, a jego ulubionym aktorem był Stan Laurel. Cenił burleski Laurela i Hardy’ego, a także wszystkich innych wielkich komików międzywojennych: Charliego Chaplina, Bustera Keatona, W.C. Fieldsa oraz braci Marx'. Lubił także filmy animowane Pata Sullivana Felix the Cat (Felix to kot-archetyp wszystkich

8 Alberto Alessandro Uderzo, syn włoskich imigrantów. Swoją karierę rysownika rozpoczął w wieku trzynastu lat w paryskim wydawnictwie, z którego wyszły Pieds Nickelés i Bibi Fricotin.

9 Biografia niezwykłych braci Marx jest kolejnym przykładem wpływu środowiska społecznego i kulturowego. Urodzili się między 1886 a 1893 r. w środowisku Manhatanu, ojciec był krawcem alzackiego pochodzenia, a matka pasjonatką show biznesu, córką niemieckiego iluzjonisty. Ich rodzina była bardzo biedna. Swoje dzieciństwo spędzili, jak pisał Harpo Marx „,w środwisku małej grupy Żydów zmiażdżonej przez Irlandczyków na północy i Niemców na południu” Fléouter, 1977 \#27117 :1\}. Bracia Marx od najmłodszych lat, pod kierunkiem Minnie, ich matki, uczą się grać. Gra dla nich burleski, kieruje nimi, podąża za nimi krok w krok, najpierw w drodze na wieczorne spektakle w parkach, na jarmarkach, stodołach, a nawet od czasu do czasu na prawdziwej scenie (od 1910 do 1915), potem w objazdowych amerykańskich teatrach wodewilowych, które rozkwitły na terenie całych Stanów i w których inni komicy, tacy jak W.-C. Fields i Harry Langdon, również uczyli się swojego fachu. To właśnie w ramach komedii burleskowej wymyślili swój styl oparty na absurdzie bez żadnych ograniczeń, na improwizacji. Swoje pierwsze przeboje na Broadwayu mieli w 1924 roku. Później w latach 1929-1949 grane były w kinach. „Wśród braci Marx Groucho był niewątpliwie liderem, pomysłodawcą i twórcą gagów, rzecznikiem i mistrzem kalamburów, gry słów, szyderstw, które na równi mogły atakować wszelkie formy rządów, zarówno demokratyczne, jak i dyktatorskie Kacza zupa (Soupe au canard, 1933) czy uniwersytety Końskie pióra (Plumes de cheval, 1932), Fléouter, Claude. 1977. „Le gai ravage”. Pp. 1 \& 15 in Le Monde. Paris. 
animowanych postaci aż do 1940 roku - Crazy Cat w Myszce Miki). Pośród filmów animowanych był także komiks argentyński: Patoruzú stworzony w 1928 roku przez Dante Quinterno. Patrząc na to z perspektywy czasu, można przypuszczać, że mógł on mieć wpływ na postacie Asterixa i Obelixa, mimo że miał swój specyficzny, unikalny styl - innymi słowy: styl ówczesnej Argentyny. Patoruzú posiadał zarówno nadludzką siłę fizyczną, jak i miłosierne, ale naiwne serce. Patoruzú posiada ten nadludzki dar wyrwania się z panującego porządku społecznego, w którym uwięzieni są jego czytelnicy, aby uświadomić im nieznośne warunki ich codziennej egzystencji. Jednocześnie oferując im świat marzeń, w którym króluje moc dawania. Ponadto poza stylem rysunkówPatoruzú niesie moralne przesłanie zarówno dla dorosłych, jak i dla dzieci, co zwiastuje rozwój nowego rynku, na którym Goscinny dobrze się odnajdze na początku lat 60 .

\section{Podatny grunt dla nowych trendów: wyłanianie się kultury młodzieżowej}

Goscinny długo źle wspominał pobyt w Nowym Jorku. W wywiadzie dla „Express” w 1974 r. powiedział: „Przyjechałem z Buenos Aires, nowoczesnego i komfortowego miasta. W Nowym Jorku wszystko było gorzkie, trudne, niezwykle okrutne” (Ory 1987). W okresie, kiedy Goscinny zmagał się z trudnościami w Nowym Jorku, komiksy były raczej skierowane do dzieci. Przypominjmy, że amerykański parodystyczny magazyn „Mad Magazine”, wydawany przez trzech nowojorskich kolegów Goscinnego, po raz pierwszy ukazał się w 1952 roku. W USA istniał podatny grunt dla rozwoju w dziedzinie, która interesowała młodych rysowników. Rok 1952 to także rok ukazania się utworu Hound Dog, w pierwszym wykonaniu Big Mamma Thorton, który czery lata później zaśpiewał Elvis Presley. Po tym jak piosenki lat 40. XX wieku zostały poddane surowemu rygorowi makkartyzmu (maccartyzm, ang. McCarthyism), w latach 50. otworzył się nowy rynek dla przemysłu muzycznego, tzw. małe giełdy (petites bourses). To „od roku 1955, [kiedy] wdzierają się «dzikie» wartości młodzieżowe, następuje ciąg innowacji i pęknięć w subkulturze młodzieżowej, nie tylko w kinie, ale również dzięki narodzinom i rozwojowi rocka” (Morin 1975b: 11).

„Począwszy od filmów, wśród których najbardziej znaczące są te z Marlonem Brando i Jamesem Deanem, których tytuły już same mówią za siebie: The Wild one (1953), Rebels without cause (1955), ukazujących nowych, prawdziwie młodzieżowych bohaterów, buntujących się przeciwko światu dorosłych i poszukujacych autentyczności. Przez falę rocka, jerka, wokół których krystalizują się nie tylko młodzieżowe upodobania do szczególnie intensywnej muzyki i tańca, ale quasi-kultura (...) pewien sposób bycia, niemal postawa wobec życia” (Morin 1975a: 181). Francuski socjolog Edgar Morin pokazał również, jak wówczas „od lokalnych erupcji do lokalnych erupcji konstytuują się dwie fale, fala uderzeniowa, która przyjmuje zarazem formę kontrkultury, jak i fala rewolucji kulturowej, szeroka fala, w której nowa kultura rozprzestrzenia się wśród młodzieży, zmienia relacje między rodzicami i dziećmi, dorosłymi i młodymi, przekształca modele zachowań, realcje miłosne i sprawia, że młodzież wyłania się jako nowa «kategoria wiekowa», nowy aktor na scenie życia społecznego i politycznego" (Morin 1975b: 11) ${ }^{10}$.

W tym czasie nowy sposób bycia specyficzny dla tej kategorii wiekowej, muzyka pop oraz inne produkty konsumenckie skierowane wyłącznie do nowej, młodej publiczności rozpowszechniły się na całym świecie.

Autor Asterixa, który został eksploratorem tego nowego rynku, skomentował pojawienie się nowej „kategorii wiekowej”. W 1965 roku w przepięknie ilustorwanej przez Cabu książce, której tytuł w języku francuskim nadal stanowi grę słów ${ }^{11}$, Goscinny przypomina, że w czasach jego młodości nie został napisany żaden utwór dla młodych, a ich siła nabywcza była wówczas równa zeru. W tamtych czasach „bycie starym było naszym największym pragnieniem, a jeżeli mieliśmy ochotę na koktail lub papierosa, to nie dlatego, że byliśmy zdeprawowani, ale dlatego, że te akcesoria stanowiły prerogatywy naszych starych" (Goscinny 1965: 9). Jednak „sytuacja się zmieniła, i w końcu świat zaczął interesować się młodymi; co nawiasem mówiąc, nie

10 Historycy i antropologowie wyjaśniają: Młodzież nie stanowi stałej kategorii antropologicznej, ale kategorię historyczną, ponieważ istnieją cywilizacje, które z socjologicznego punktu widzenia nie mają młodzieży.

11 Zupa potage to bulion warzywny. Wyrażenie „zupa została podana” zachęca tych, którzy sami jej nie przygotowali, aby przyszli i usiedli przy stole, aby ją skonsumować. W niektórych regionach Francji, gdzie Asterix będzie bawić, „g” wymawia się jako „ch”, a zatem słowo zupa przypomina potache, co potocznie oznacza ucznia college’u lub liceum. Tytuł książki Le potache est servi jest aluzją do młodych ludzi, którzy muszą jedynie obsłużyć się przy stole społeczeństwa konsumpcyjnego. 
zawsze jest dobrym znakiem. Zazou trafiało na pierwsze strony gazet, co było zapowiedzią yé-yé, jednak nie był to jeszcze dobry czas ani aby być młodym, ani... dorosłym. A teraz wszystko się zmieniło. Liczni bogaci, ważni młodzi stali się masą, z którą należy się liczyć. Są nie tylko przyszłością, ale również teraźniejszością naszego kraju. $Z$ pojedynczych fenomenów stali się fenomenem społecznym. Pozwalają sobie schlebiać, karzą się siebie bać i podziwiać z protekcjonalną wyższością. Dla nich tłoczone są płyty, tworzone tańce, wprowadzane mody, wymyślane drinki, przekształcne programy szkolne i choć jeszcze do niedawna mieli prawo tylko do kilku nieprzychylnych artykułów dziś poświęca się im całe gazety, które osiągają kolosalne nakłady. Teraz przyszła kolej na dorosłych, aby się wstydzić. To oni przyjmują, jeśli jest to możliwe, modę swoich dzieci" (Goscinny 1963: 9).

To właśnie w Ameryce Północnej w ostatniej dekadzie XIX wieku pojawiły się pierwsze komiksy. Tłumaczy się to specyficznym kontekstem kulturowym. Stany Zjednoczone doświadczały w tym okresie bardzo szybkiego rozwoju, a ich populację stanowiła ludność o bardzo różnorodnym pochodzeniu, mówiąca różnymi językami, dla której czytanie prasy w języku angielskim nie zawsze było czymś oczywistym. Dlatego też w najpopularniejszych gazetach rozpowszechnił się zwyczaj wykorzystywania ilustracji, a także publikowania w niedzielnych wydaniach kolorowych, sugestywnych, kuszących i zabawnych cztero- lub ośmiostronicowych suplementów, przeznaczonych zarówno dla dorosłych, jak i dla dzieci. Włoski semiolog Daniele Barbieri, przedstawiając okoliczności pojawienia się komiksu, podkreśla, że jego narodziny „,same w sobie są manifestacją wybuchowego fenomenu kultury" (Barbieri 2014).

W 1895 roku w Stanach Zjednoczonych ukazała się seria dużych, całostronnicowych humorystycznych kreskówek, ilustrujących w sposób sarkastyczny codzienne życie ulicy w typowej imigranckiej dzielnicy. Pomiędzy postaciami wyróżniał się irlandzki chłopak, zawsze ubrany w żółtą koszulę. Wkrótce stał się on niekwestionowanym bohaterem i od jego postaci weźmie tytuł serii: The Yellow Kid. W kolejnym roku, w 1896, zastosowano po raz pierwszy podział rysunków na pola i pasma, na linie ruchu wzmacnające dynamikę, pojawiły się także dymki zawierające słowa (inaczej mówiąc: filakterie). Są to podstawowe elementy tego, co odtąd w Stanach Zjednoczonych będzie nazywane komiksem. „Niedzielna strona Yellow Kid (pojedyncza, autonomiczna strona) będzie więc stanowić przez pierwsze dziesięć lat wzór komiksu, w szybkim pomnażaniu udanych postaci (często z wykorzystaniem metod komercyjnych nieróżniących się zbytnio od dzisiejszych, z reklamowym wykorzystaniem postaci i eksploatacją poprzez merchandising)" (Barbieri 2014).

Po okresie ukazywania się tylko w niedzielnym suplemencie, kilka lat później komiksy wychodziły już siedem dni w tygodniu (po raz pierwszy w 1907 roku), na specjalnej stronie zarezerwowanej dla nich, w formie pasków zawierajacych po trzy lub cztery czarno-białe pola. „Te historyjki obrazkowe (comic strips), nazywane także funnies, a później przez niektórych historyków newspaper strips (paskami gazetowymi), bawiły całe społeczeństwo amerykańskie. Codzienne spotkania z nimi, dzień po dniu, przez kolejne lata zrodziły między czytelnikiem a bohaterami nie tylko zjawisko uzależnienia, ale i niezwykłą bliskość: papierowi bohaterowie stali się niemal częścią rodziny" (Groensteen 2017: 55).

Pojawienie się komiksu w Stanach Zjednoczonych było fenomenem kulturowym tak niezwykłym, że pierwsi ich autorzy od razu odnieśli tak ogromny sukces, że walczyli z dolarami oraz prowadzili batalie sądowe z potentatami prasowymi. Z pewnością przyczyniło się to do tego, że kolejne pokolenia marzyły o nowych innowacjach medialnych, na przykład w kinie, którego historia rozpocznie się w 1915 roku wraz z filmami Narodziny narodu (Birth of a Nation, 1915) Davida Griffitha oraz Imigrant (The Immigrant, 1917) Charliego Chaplina.

\section{O czasoprzestrzennej ewolucji uniwersalnego charakteru}

Charlie Chaplin (Charlot) jest postacią tak samo uniwersalną, jak brzydkie kaczątko Hansa Christiana Andersena (1805-1875) czy Pinokio Carla Collodiego (1826-1890), które pojawiły się wiek wcześniej. Jendak Charlie Chaplin pojawia się i natychmiast dzięki rozpowszechnieniu za pośrednictwem nowych mediów kinomatograficznych zyskuje dużo szerszą od nich publiczność.

Jednak ów postęp w zakresie upowszechnienia nowych mediów nie może nam przysłonić faktu, że na początku XX wieku nadal istnieje związek między postacią Charliego Chaplina, naturą jego relacji 
z publicznością a popularnymi postaciami z ubiegłego stulecia powstałymi po drugiej stronie Ocenanu Atlantyckiego. Pozwala nam to rzucić światło na naturę więzi społeczno-kulturowych, które sprzyjały kreatywności i rozwojowi rynku.

Pojawiając się po raz pierwszy na ekranie w 1914 roku, Charlie Chaplin (Charlot) zyskał bardzo szybko ogromną popularność na całym świecie. Postrzegany był jako typ uniwersalny, symbol nieustannej walki o godność i wolność jednostki ${ }^{12}$.

Jednocześnie należy pamiętać, że swoją reputację Charlie Chaplin oparł na komediowej modzie wywodzącej się między innymi z commedii dell’arte (komedii ludowej).

Przed epoką romantyzmu, kiedy to bajki zyskały na popularności między innymi dzięki braciom Grimm (których baśnie były publikowane w Niemczech od 1812 roku), dramaturg, autor commedii dell'arte Carlo Gozzi (1720-1806), rozpowszechnił wyreżyserowane, w zmienionej formie, opowieści ludowe. To, co należy w tym miejscu podkreślić, to przechodzenie z jednej formy komunikacji do drugiej, wchodzenie w spiralę komunikacji opartej w tej epoce głównie na przekazie ustnym.

Większość społeczeństwa nadal pozostawała niepiśmienna, komunikacja za pośrednictwem książki czy czasopisma była mocno ograniczona. Wielką zaletą commedii dell’arte ${ }^{13}$ i teatrów kukiełkowych był fakt, że docierały one do publiczności mówiącej różnymi językami i dialektami (tak samo było w przypadku niemego kina). To umożliwiło rozpowszechnianie ich na skalę globalną. Bohaterami były postacie o takich samych sylwetkach, imionach czy tikach. Odnajdywano ich, sztuka po sztuce. Fabuła była bardzo prosta ${ }^{14}$.

12 Twórczość Charliego Chaplina porusza temat walki o godność i wolność, a także potrzebę miłości i wrażliwości, przywołując jednocześnie zakazy i upokorzenia.

13 Commedia dell'arte to teatr profesjonalny. Spadkobiercy tradycji, która sięga antycznego teatru mimów, aktorzy commedia dell'arte są wędrującą trupą opłacaną przez publiczność. Na długo zanim pojawiła się kwestia profesjonalizacji gry aktorskiej, renesans zaanosował się w Rzymie, Wenecji i oczywiście we Florencji przez niezliczone tłumaczenia i pastisze antycznych sztuk teatralnych oglądanych przez Rzymian. Ten teatr antyczny, który możemy określić mianem „uczonego” (commedia erudita, przyp. tłum.), pojawił się we Włoszech już pod koniec średniowiecza, sto lat wcześniej niż w innych częściach Europy. Wyjaśnia się to tym, że miały tam miejsce wielkie wykopaliska archeologiczne. „Często pośród starożytnych ruin odgrywany jest na przemian Terencjusz lub też zaniedbany teatr religijny”, Degaine, André. 1993. Histoire du théatre en bande dessinée. Paris: Nizet, 3 place de la Sorbonne. „Elitarny teatr, ale znacznie mniej zamknięty w murach szkolnych, niż to będzie we Francji, w XVI wieku. Na wyrafinowanych i okazałych dziedzińcach półwyspu zawsze się świętuje. Ten (nowy) teatr jest uprawiany równolegle z Karnawałem, którego groteskowe i zamaskowane postacie od zarania dziejów cieszą się ogromną popularnością", ibid.

Była również „farsa”, która jest poprzedniczką komedii obyczajowej i komedii intrygi, zaczerpniętej z popularnych fabliaux. Odnośnie do farsy, André Degaine, w swojej fascynującej Historii teatru rysowanego: od prehistorii do wspótczesności, wszystkie czasy i wszystkie kraje, zastanawia się, „,czy wzięła ona swoją nazwę od pojęcia mieszania różnych elementów, czy od porównania z farszem i jego przyprawami dorzucanymi do dania głównego, w tym przypadku do Misteriów?”, ibid. Słowo „misterium” oznacza spektakl, który pojawił się na początku XV wieku: „Tak jak w Grecji, tak i w Rzymie oferują na dziedzińcu lub na placu ogólnodostępnym dla wszystkich - dla wszystkich klas łącznie - nauczanie (tutaj Świętej Historii) w formie rozrywki”, ibid.

W połowie XVI wieku powstały profesjonalne trupy zdolne do zagrania wszystkiego, czego życzyła sobie publiczność: od teatru uczonego po farsę, nie wahając się przy tym użyć masek karnawałowej komedii. „To dzięki farsie stali się rozpoznawalni wszędzie: W Hiszpanii, w Niemczech, a zwłaszcza we Francji. Do tego stopnia, że termin Commedia dell'Arte ogólnie (teatr profesjonalny) zaczyna odnosić się wyłącznie do improwizowanej gry w maskach, ze stałymi, gadatliwymi i akrobatycznymi postaciami. Comédiens de l’Art grane są wszędzie (ulica, pałac) zarówno prywatnie, jak i publicznie. Wędrowne, «kręcą się» w nieskończoność”, ibid. Każdy aktor posiada swoją osobowość, określony typ, z którym jest identyfikowny (Harlequin, Mezzetin, Pantalone, The Doctor, Brighella, Colombine). Na jej łonie „z wykluczeniem wszelkiego intelektualizmu i wszelkich efektów psychologicznych, tkwi sztuka aktorska (...) zasadniczo w cielesnej ekspresji: musi on być panem swego głosu i swojego ciała do tego stopnia, że może ich użyć jako prawdziwych instrumentów. Pantomimy, entrechaty, lazzi rzeczywiście wymagają akrobatycznej elastyczności i nieustannej inwencji. Commedia dell'arte bardziej ufa wyobraźni niż pamięci i ruchowi niż językowi”, Abirached, Robert. 1999. „Commedia dell'arte", in Universalis. Paris: Universalis.

Z Włoch commedia dell'arte rozprzestrzeniła się od XVI do XVIII wieku w całej Europie, „gdzie pozostawiła głębokie ślady w wyobraźni ludowej, jak również w teatrze, poezji i sztuce. Wiele z jej postaci zmieszało się z postaciami produkowanymi przez różne folklory narodowe lub przyczyniło się do powstania nowych", ibid.

14 Tradycja sięga znacznie dalej: tak też postąpił wielki Molier (1622-1673), który również uprawiał teatr wiejski, Mnouchkine, Ariane. 1978. „Molière”. Pp. 244. France, ale dodając dla swojej wykształconej publiczności bardziej rozbudowane teksty. Pisarze zbierali lokalne opowieści, które w tradycji oralnej krążyły w różnych częściach świata, robili to w lokalnych językach i rozpowszechniali je na materiale niedostępnym dla zbyt wielu: w książkach. Tak więc w XVII wieku Giambattista Basile (15751632) i Charles Perrault (1628-1703) pisali w czasach, kiedy liteatura dziecięca nie istniała jeszcze w dziedzinie sztuki naukowej 
Precyzując, to ten rodzaj akcji, który odnajdujemy w komedii filmowej z okresu Maxa Lindera i Charliego Chaplina. W kolejnych epokach odnajdujemy Harlequina i inne charakterystyczne postacie latwo rozpoznawane przez publiczność. Powstające kino było jak pokaz jarmarczny. To, co było wspólne zarówno dla nowoczesnego Charlesa Chaplina, jak i dla uniwersalnych postaci z commedii dell'arte z poprzednich stuleci, to ich popularność w dosłownym tego słowa znaczeniu: są popularni, to znaczy „gotowi do zdobycia przychylności ludzi” natychmiast, bez tłumaczenia. Jak już zaznaczyłem powyżej: na początku XX wieku Stany Zjednoczone doświadczyły szybkiego rozwoju demograficznego, a ich populacja składała się z osób o bardzo zróżnicowanym pochodzeniu, mówiących różnymi językami. Dla ówczesnej ludności nieme kino było bardzo atrakcyjne ze względu na prostotę przekazu i zabawną formę, oparte na tych samych uniwersaliach co commedia dell'arte.

Ponadto, podobnie jak bohaterowie popularnych baśni, bohaterowie niemych filmów odwołują się do wolności i godności. Jednakże sposób wyrażania godności i wolności ewoluował. Charlie Chaplin nie jest Pinokiem, a tym bardziej brzydkim kaczątkiem. Społeczeństwo przemysłowe już przez to przeszło. Nie ma już odniesień do wiejskiego życia, postacie nie są już ani szlachcicami, ani chłopami ${ }^{15}$. Są jeszcze bardziej banalne, bardziej pospolite.

Kino jako pierwsze zgromadziło widzów ze wszystkich warstw miejskich, a nawet wiejskich, tym samym burząc stosunki wewnątrz kraju i między pokoleniami, zarówno na poziomie lokalnym, jak i globalnym.

Już w latach 60. francuski socjolog Edgar Morin podkreślał, że „kultura przemysłowa rozwija się na planie rynku światowego. Stąd jej ogromna skłonność do synkretyzmu - eklektyzmu oraz homogenizacji. Bez całkowitego przełamywania zróżnicowania jej wyimagnowany, zabawny, estetyczny przekaz przełamuje bariery lokalne, etniczne, społeczne, narodowe, wieku, płci, wykształcenia; wyrywa z folkloru i z tradycji tematy, które uniwersalizuje, wymyśla tematy, które od początku stają się uniwersalne" (Morin 1983: 47). Kultura przemysłowa adaptuje lokalne ludowe (folklorystyczne) motywy i transformuje je w motywy kosmopolityczne, takie jak western, jazz, tropikalne rytmy i inne. „Podejmując ten kosmopolityczny bum, promuje z jednej strony synkretyzm kulturowy (koprodukcje filmowe, przeszczepianie tematów z jednego obszaru kulturowego do innego), a z drugiej strony tematy «antropologiczne», to znaczy dostosowane do wspólnego mianownika ludzkości” (Morin 1975a: 57).

ani w formie druku, ale jedynie jako popularna tradycja ustna. Basile napisał swoje baśnie w języku lokalnym - napolitańskim, a Perrault w języku budowanym dopiero w procesie popularyzacji - francuskim, który nie był przez zbyt wielu rozumiany. Ponadto należy zauważyć, że dzieci nie stanowiły w tym czasie odrębnej publiczności, można było mieszać repertuar dziecięcy z repertuarem popularnym. Teatry popularne, tak jak commedia dell’arte, bawiły wszystkich bez różnicy i w spontaniczny sposób.

15 O ewolucji społeczeństwa między stuleciem Pinokia a stuleciem Charlesa Chaplina, pozwólcie, że odeślę was do niektórych z moich innych prac: Bouchet, Dominique. 1994. „Rails without ties. The social imaginary and postmodern culture. Can postmodern consumption replace modern questioning?” International Journal of Research in Marketing No 11(September 1994): 405-22, 1995; „Marketing and the Redifinition of Ethnicity”. Pp. 68-104 in Marketing in a Multicultural World. Ethnicity, Nationalism, and Cultural Identity, edited by Janeen Arnold Costa and Gary J. Bamossy. Thousand Oaks - London - New Delhi: Sage, 1996; „Marketing jako szczególna forma komunikacji” in Komunikacja międzykulturowa. Zderzenia i spotkania, edited by Leszek Korporowicz. Warszawa, Poland Universitatis Varsoviensis Instytut Kultury \& Instytut Socjologii, Uniwersytetu Warszawskiego, 1998; „Information technology, the social bond and the city. Georg Simmel updated. About the changing relationship between identity and the city". Built Environment 24(2/3, 1998): 104-33, 2005. Simmel og den sprangte by. Om de indbyrdes relationer mellem sociale forandringer, informationsteknologien og by-udviklingen hundrede år efter Georg Simmel banebrydende sociologiske analyser. Copenhagen: Billedkunstskolernes Forlag, 2011a; „Political Economy”. Pp. 1101-04 in Encyclopedia of Consumer Culture. Volume 3, edited by Dale Southerton. Los Angeles \& London: Sage, 2011b; „Social and Economic Development”. Pp. 1305-10 in Encyclopedia of Consumer Culture. Volume 3, edited by Dale Southerton. Los Angeles \& London: Sage, 2015. „Smith, Adam (1723-1790)”. Pp. 118-24 in International Encyclopedia of the Social and Behavioral Sciences. 2nd Edition, edited by James D. Wright. New York: Elsevier, 2017; Adam Smith, „Market and Social change: Then and Now”. Markets, Globalization \& Development Review (MGDR) 2(1), 2018; „Marketing, violence and social cohesion: First steps to a conceptual approach to the understanding of the normalising role of marketing". Journal of Marketing Management, Vol. 34, 2018, Issue 11-12: Violence, Markets and Marketing, $1048-62$. 


\section{Asterix jako surfer po kosmopolityzmie}

Wciągnięty w wir kultury masowej, która rozwinie się w okresie jego dorastania w Brazylii i podczas stażu w Nowym Jorku w latach 40., René Goscinny pojawił się, aby wnieść swój wkład w przemiany: komiksy o Asterixie będą partycypować w tej „kulturze przemysłowej”, łamiąc bariery społeczne, wieku, wykształcenia i adaptując różne lokalne tematy do globalnego rynku.

Zmiany stylu życia ludzi, a zwłaszcza fundamentalna różnica między starymi a nowymi formami dystrybucji i konsumpcji produktów kulturowych (prasy, kina i trochę później telewizji) zaburzą relacje między krajami i generacjami, zarówno na poziomie lokalnym, jak i globalnym.

W okresie międzywojennym komiksy przeżyły swój pierwszy boom i stały się przedmiotem masowej konsumpcji ${ }^{16}$. Przede wszystkim jednak było to wszechobejmujące zjawisko masowej konsumpcji, które reorganizując granice i relacje między państwami i pokoleniami, zarówno na poziomie lokalnym, jak i globlnym, stało się pożywką dla powstającej nowej kultury młodzieżowej lat 60. To właśnie w Ameryce Północnej René Goscinny natknął się zarówno na „lokalnych” rysowników próbujących wedrzeć się na rynek, jak i na francuskich i belgijskich twórców zwabionych tym, co się działo po drugiej stronie Atlantyku. Wszyscy oni debiutowali w sprzyjających warunkach, aczkolwiek w niezbyt przyjaznym środowisku. To ich nowe idee dostosowane do nowego segmentu rynku pozwoliły na przebicie się na poziomie lokalnym i globalnym. Dokładnie to samo zrobił przed nimi Walt Disney.

René Goscinny najpierw trafił do Belgii, ówczesnej mekki komiksu frankofońskiego i europejskiego. Było to (pozycja Belgii przyp. tłum.) efektem geopolitycznej osobliwości, dobrze wyjaśnionej przez Pascala Ory, którego pozwolę sobie tu obszernie zacytować: „Jeśli Belgia jest tym, czym jest - a raczej była tym, czym była - to z powodów, które prowadzą w prostej linii od 1550 do 1950 roku, innymi słowy, od teologii do komiksu, i można to podsumować w jednej formule: kontrreformacja lub reformacja katolicka. Mówiąc dokładniej, chodzi mi tu o względną skuteczność hiszpańskiej kontrofensywy, która arbitralnie wyznaczyła granicę między przyszłą protestancką Holandią i przyszłą katolicką Belgią. Jeżeli chodzi o tę "częściową" skuteczność, to zasadniczo jest ona wynikiem rozwoju, gdzieś pomiędzy soborem trydenckim a Towarzystwem Jezusowym, magicznej formuły: nowoczesność form w służbie tradycji. Wiedzy o tym, jak szerzyć dobrą nowinę metodami jak najbardziej dostępnymi dla «dobrych ludzi» - innymi słowy «niższym ludziom» arystokracie przetransformowanego przez chrystologię - oto cała tajemnica, żadne czary "propagandy» (słowo wymyślone na tę okazję: propaganda fidei)” (Ory 1987: 69-70). W okresie, kiedy Goscinny przybył do Europy, wydawano gazety „Tintin” i „Spirou” w Belgii oraz „Le journal de Mickey” we Francji.

W rzeczywistości, kiedy w 1951 roku Goscinny dołączył do szkoły francusko-belgijskiej, była ona kontrolowana przez belgijskie autorytety religijne. W efekcie „Spirou” było stale czytane przez jezuitę (Ory 1987: 91). Istniała zatem ogromna różnica w porównaniu z tym, co działo się po drugiej stronie Atlantyku, gdzie rozpowszechnaiały się komiksy przepełnione przemocą i seksualnością, które powoli, ale systematycznie zaczynały wkraczać również na rynek europejski. Utrzymanie komiksów w stylu dziecięcym zostało odgórnie narzucone zarówno we Francji, jak i w Belgii: we Francji ustawa z 1949 roku przyczyniła się do utrzymywania komiksów w stylu dziecięcym. Przepis ten wprowadzono, ponieważ po II wojnie światowej społeczeństwo francuskie było mocno zdestabilizowane. Przestępczość wśród nieletnich rosła w sposób bezprecedensowy: w 1946 roku przed sądami dla nieletnich stanęło 31000 osób, czyli trzy razy więcej niż w 1936 r. Ponadto prawie wszyscy sędziowie, psycholodzy, dziennikarze, pracownicy socjalni wskazywali w swoich raportach na zgubny wpływ kina i prasy. W efekcie komiksy zostały prawnie utrzymane w nurcie dziecięcym. Goscinny pisał zatem scenariusze dla dzieci, które nie zawierały nic szokującego dla cenzorów, ale jednocześnie pełne były aluzji, które mogły rozbawić dorosłych. W pewnym sensie postępował podobnie do Charles'a Perrault (1628-1703), który w swoich słynnych baśniach, opublikowanych w 1697 roku, pod przykrywką lekkiej

16 „Cykl I ery masowej konsumpcji rozpoczyna się około 1880 roku, a kończy wraz z II wojną światową. W fazie I małe rynki lokalne są zastępowane przez duże rynki krajowe, co jest możliwe dzięki nowym warunkom produkcji przemysłowej oraz nowoczesnej infrastrukturze transportowej i komunikacyjnej (koleje, telegrafy, telefony), w której rozpowszechniają się nowe zrównoważone produkty oraz nowe metody i procesy produkcji przemysłowej zdolne do masowej produkcji znormalizowanych towarów po niskich cenach” Lipovetsky, Gilles. 2003. „La société d’hyperconsommation”. Le Débat 124 (mars-avril 2003): 74-98. 
i dziecięcej rozrywki przemycał swoje poglądy teoretyczne ${ }^{17}$, mnożył aluzje, robił przytyki i innsynuacje wobec swojej światowej publiczności. Jednak rynek baśni Perraulta czy sto lat później rynek baśni Andersena nie miały nic wspólnego z masowym rynkiem rozwiniętym w pierwszej połowie XX wieku.

W latach 60. Goscinny z pełnym zaangażowaniem uczestniczył w ruchu na rzecz legitymizacji i zróżnicowania kultury masowej, aby szybko odnieść sukces w Paryżu jako scenarzysta w okresie, gdy nadal tak naprawdę tylko rysownicy byli uznawani ${ }^{18}$. W tandemie od 1951 roku scenarzysta René Goscinny i wielki rysownik Albert Uderzo, który tak świetnie potrafił zilustrować postacie, wydobywając ich mimikę i niesamowicie dynamiczne gesty, stworzyli w 1959 roku komiks o Asterixie. Jego cechą charakterystyczną było to, że zarówno akcje, dialogi, jak i rysunki mogły być odczytywane i rozumiane w odmienny sposób przez dzieci i dorosłych.

To nie był już czas króla słońca ani romantyzmu. To nie był też już czas niemego kina. Oferta kulturalna była bogata. Różne czasopisma, filmy, książki i komiksy adresowane do różnych odbiorców. Goscinny chciał zrobić komiks dla wszystich, nie tylko dla dorosłych czy tylko dla dzieci. Aby było to możliwe, wiedział, że nie może szukać wspólnego mianownika, ale raczej spowodować, żeby czytanie odbywało się na dwóch różnych poziomach. Tam, gdzie dzieci dostrzegałyby tylko akcję, dorośli bawiliby się aluzjami zrozumiałymi tylko dla tych, którzy mają niezbędną wiedzę, aby je zrozumieć. Mogą to być aluzje do tego, co dzieje się w polityce krajowej lub międzynarodowej. Mogą to być odniesienia do tego, czego nauczyli się dorośli, gdy byli w szkole, i czego już nowe pokolenia mogą się nie uczyć. Te aluzje mogą być we fragmentach scenariuszy, w zdaniach związanych z karykaturami postaci, które dorośli łatwo rozpoznają, niezależnie od tego, czy są to aktorzy, piosenkarze, czy politycy współcześni lub dawni, Francuzi, Europejczycy, Amerykanie ${ }^{19}$, postacie $\mathrm{z}$ innych dzieł literackich.

\section{Migracje kulturowe i twórczość}

Albert Uderzo był również synem imigranta, urodził się we Francji, ale miał włoskie obywatestwo. Jak już pisałem, René Goscinny poznał Alberta Uderzo, kiedy po powrocie do Francji w 1951 roku powierzono mu odpowiedzialność za paryski oddział małej brukselskiej agencji prasowej World Press.

Tak więc Goscinny i Uderzo, podobnie jak wielu innych francuskich przedstawicieli świata kultury, nauki i polityki, są imigrantami ${ }^{20}$. W imponującym Stowniku cudzoziemców, którzy stworzyli Francję (Dictionnaire

17 Charles Perrault zainicjował spór tzw. starożytników (zwolenników antyku) z nowożytnikami (zwolennikami kultury współczesnej). W swoich dziełach porównywał kulturę rodzimą z antykiem, postulując konieczność zastąpienia antycznych wzorów dominuących w ówczesnej literaturze przez literaturę francuską pisaną w rodzimym języku (przyp. tłum.).

18 W środowisku francusko-belgijskich twórców komiksów lat 50. scenarzysta nie był opłacany przez wydawcę i uznawany za takiego, jakim jest dzisiaj. W 1956 roku nagle wybucha kryzys. „Charlier, Goscinny i Uderzo znajdują się w czołówce niewielkiej grupy autorów, którzy pracują dla World lub na arenie międzynarodowej, łączą siły w celu uzyskania nie tylko lepszych warunków wynagrodzenia, ale przede wszystkim uznania szczególnego charakteru ich pracy, zgodnego z francuską tradycją praw autorskich, w przeciwieństwie do anglosaskiej tradycji sprzedaży praw autorskich. Są oni tym bardziej zmotywowani, że spotykają się z odmiennym traktowaniem pracowników agencji i «freelancerów», takich jak Morris, Franquin czy Peyo, zatrudnionych bezpośrednio przez Dupuis i wynagradzanych z tytułu praw autorskich w stylu francuskim. Do tego dochodzi konkretne roszczenie scenarzystów, pomijane w umowach podpisanych przez wydawcę z jedynym z rysowników”, Ory, Pascal (Ed.). 1987. Goscinny. La liberté d'en rire. Paris: Perrin.

19 Tacy jak: Les Beatles, Brigitte Bardot, Sean Connery, Tony Curtis, Kirk Douglas, Jean Gabin, Charles Laughton, Stan Laurel i Oliver Hardy, Jean Marais, Yves Montand, Eddy Merckx, Luciano Pavarotti, Pierre Tchernia, Lino Ventura, Benito Mussolini, Król Słońca Ludwik XIV.

20 W latach 60. XX wieku wiele osobistości obcego pochodzenia zostało uznanych za twórców znacznej części francuskiego dziedzictwa. Jako przykład mała, niewyczerpująca lista: Charles Aznavour, Yves Montand, Serge Reggiani, Lino Ventura, Jacques Canetti, Serge Gainsbourg, Louis de Funès, Coluche, Jacques Tati w świecie piosenki i kina, Émile Zola, Blaise Cendrars, Samuel Beckett, Eugène Ionesco, Milan Kundera, Émil Cioran, Romain Gary, Joseph Kessel, Irène Némirovsky, Vercors, Nathalie Sarraute, Henri Troyat, Marguerite Yourcenar w dziedzinie literatury; Alechinsky, Picasso, Kandinsky, Christo, le Corbusier w sztuce; André Gorz, Edgar Morin, Cornélius Castoriadis, Catherine Dolto, Alexandre Kojève, Alain Minc, Benjamin Stora wśród intelektualistów, Marie Curie, Georges Charpak wśród naukowców uhonorowanych Nagrodą Nobla, Pierre Cardin, Karl Lagerfeld, Paco Rabanne, Nina Ricci w świecie mody, Leon Zitrone, Françoise Giroud, Michel Drucker, Michel Cymès, Pierre Tchernia, François Cavanna w mediach. 
des étrangers qui ont fait la France), liczącym prawie 1000 stron i zawierającym ponad 1200 pozycji, możemy przeczytać, że „miliony Francuzów mają dziś przodków obcego pochodzenia w przeciągu trzech lub czterech pokoleń" (Ory 2013)

Co więcej, w momencie premiery Asterixa spora liczba mieszkańców Paryża bardzo często odwoływała się do swojego prowincjonalnego pochodzenia, wspominając, skąd pochodzili ich rodzice i dziadkowie ${ }^{22}$. Należy pamiętać, że w latach 20. ubiegłego wieku perturbacje polityczne w wielu krajach Europy Wschodniej skłoniły wiele osób do szukania schronienia we Francji. Na przykład w Polce Żydzi spotykali się z prześladowaniami/przemocą i dyskryminacją. Trudno było im kontynuować studia czy pracować w swoim zawodzie ${ }^{23}$. W 1922 roku w pogrążonych w kryzysie Włoszech doszło do zamachu stanu w trakcie marszu na Rzym, w wyniku którego Mussolini uzyskał władzę ${ }^{24}$. Po tym wydarzeniu zmienił się profil włoskiego imigranta. Włosi chętniej będą odtąd migrować do Francji niż do Stanów Zjednoczonych. Na początku lat 30. XX wieku w Europie Wschodniej, w ślad za faszystowskimi Włochami, ustanawiają się reżimy autorytarne. Kiedy sytuacja w krajach pochodzenia stawała się coraz trudniejsza, marginalizowane jednostki przyciągał świetlisty obraz Francji, państwa praw człowieka: Francji oświecenia, wysepki demokracji i dobrobytu, gdzie szkoła była świecka, darmowa i obowiązkowa, a asymilacja pożądana przez państwo ${ }^{25}$.

W swojej książce Astérix ou la parodie des identités (Asterix, czyli parodia tożsamości) Nicolas Rouviére podkreśla, że zarówno Goscinny, jak i Uderzo „doświadczyli trudności związanych z integracją z kulturą, która nie była ich własną, a także politycznych i społecznych skutków rasizmu. Obaj cierpieli z powodu uprzedzeń, jakie każdy żywi o sobie i innych. Formuła ta brzmi więc jak zabezpieczenie: wskazuje, że kryzys tożsamości jest być może tylko deficytem inności w skali indywidualnej i zbiorowej. Dlatego uzasadnione jest studiowanie Asterixa jako przygody z tożsamością, w której wyzwaniem jest zintegrowanie części innego, w celu zbudowania siebie" (Rouvière 2008: 21).

Ttumaczenie Kinga Lendzion

21 Tłumaczy to między innymi fakt, że w okresie rozwoju przemysłowego w latach 1830-1860 znacznie wzrosła migracja zarobkowa. W trakcie i po Rewolucji Francuskiej kraj praw człowieka przyciągał liberałów wszelkiego pochodzenia, którzy przybyli, aby znaleźć tam schronienie i zaciągnąć się pod jej sztandary, Temine, Émile. 1999. France, terre d’immigration. Paris: Gallimard (Collection Découvertes Numéro 380). Tak więc, „według szacunków, liczba obcokrajowców we Francji pod koniec Drugiego Cesarstwa oscylowała pomiędzy 700000 a 800000 osób. Przybyli oni ze wszystkich części Europy, a nawet ze świata śródziemnomorskiego", ibid. i dalej: „w latach 1875-1930 rosnące zapotrzebowanie na siłę roboczą, spadająca liczba urodzeń, pogłębiona przez straty w ludziach poniesione podczas Wielkiej Wojny doprowadziły do masowej migracji do Francji. Początkowo imigranci przybywali z krajów granicznych (Włochy, Belgia), później migracja objęła również inne populacje, z Europy Środkowej, czy z imperium kolonialnego”, ibid. „Ekspansja przemysłowa i niski współczynnik urodzeń sprawiły, że Francja była jedynym krajem w Europie importującym siłę roboczą. Populacja obcokrajowców wzrosła z 1\% w 1851 roku do 2,6\% w 1901 roku”, Vial, Éric. 1999. „Immigrés et étrangers". Pp. 642-51 in La France d'un siècle à l'autre. 1914-2000. Dictionnaire critique, edited by François Sirinelli and Jean-Pierre Rioux. Paris: Hachette, do 1 miliona w 1911 roku, 1,5 miliona w 1921 roku, „2,4 miliona w 1926 i 2,9 w 1931 roku, co stanowiło 7\% ludności, skoncentrowanej głównie w regionach przygranicznych i wokół Paryża. Ibid. Międzynarodowy kryzys ekonmiczny w 1929 roku wszystko zmienił: „Wszystko zmieniło się w 1931, wraz z kryzysem”, ibid. „Nie przekraczając nigdy 10\% populacji, 8 milionów imigrantów osiedliło się we Francji w przeciągu 150 lat. Nie sposób sobie wyobrazić, czym byłaby Francja bez tego wkładu: według obliczeń ekspertów populacja francuska spadła o połowę, przy 40-procentowym spadku urodzeń”, Aderhold, Carl, and Françoise Davisse. 2019. Histoires d'une nation: Stock.

22 Na przykład w trakcie spotkań z kimś za granicą lub w trakcie wakacji pytali, skąd pochodzi.

23 W 1921 roku ponad 70000 polskich Żydów wyemigrowało do Stanów Zjednoczonych, a między 1921 a 1925 rokiem ponad 180000 Żydów opuściło Polskę. W 1935 roku dyskryminacja stała się jeszcze bardziej widoczna przez wprowadzenie na polskich uczelniach tzw. getta ławkowego", Gutwirth, Jacques. 2011. Être juif en Pologne. Mille ans d'histoire. Du Moyen âge à 1939. Paris: Albin Michel. Niektórzy z polskich imigrantów uciekli do Francji, ponieważ w kraju byli prześladowani zarówno jako Żydzi, jak też jako komuniści.

24 Mussolini był pierwszym populistycznym przywódcą XX wieku, który masowo wykorzystywał radio i kino.

25 Sytuacja gospodarcza i polityczna we Francji również ewoluowała w kierunku mniejszej tolerancji wobec imigrantów. Na przykład kiedy wprowadzono numérus clausus, wielu imigrantów nie mogło podjąć już studiów, mimo że wybrali Francję rewolucji i wolności. 


\section{Bibliografia}

Abirached R. (1999), Commedia dell'arte [w: Universalis. Paris: Universalis.

Aderhold C., Davisse F. (2019), Histoires d'une nation: Stock.

Barbieri D. (2014), Breve storia della letteratura a fumetti. Roma: Carocci.

Bouchet D. (1994), Rails without ties. The social imaginary and postmodern culture. Can postmodern consumption replace modern questioning?. „International Journal of Research in Marketing” 11(September): 405-422.

Bouchet D. (1995), Marketing and the Redifinition of Ethnicity [w:] J.A. Costa i G.J. Bamossy (red.), Marketing in a Multicultural World. Ethnicity, Nationalism, and Cultural Identity, Thousand Oaks - London - New Delhi: Sage, s. 68-104.

Bouchet D. (1996), Marketingjako szczególna forma komunikacji [w:] L. Korporowicz (red.), Komunikacja międzykulturowa. Zderzenia i spotkania. Warszawa: Instytut Kultury i Instytut Socjologii, Uniwersytet Warszawski.

Bouchet D. (1998), Information technology, the social bond and the city. Georg Simmel updated. About the changing relationship between identity and the city. „Built Environment” 24(2/3), s. 104-133.

Bouchet D. (2005), Simmel og den sprengte by. Om de indbyrdes relationer mellem sociale forandringer, informationsteknologien og by-udviklingen hundrede år efter Georg Simmel banebrydende sociologiske analyser. Copenhagen: Billedkunstskolernes Forlag.

Bouchet D. (2011a), Political Economy [w:] D. Southerton (red.), Encyclopedia of Consumer Culture. Volume 3, Los Angeles \& London: Sage, s. 1101-1104.

Bouchet D. (2011b), Social and Economic Development [w:] D. Southerton (red.), Encyclopedia of Consumer Culture. Volume 3, Los Angeles \& London: Sage, s. 1305-1310.

Bouchet D. (2015), Smith, Adam (1723-1790) [w:] J.D. Wright (red.), International Encyclopedia of the Social and Behavioral Sciences. 2nd Edition, New York: Elsevier, s. 118-24.

Bouchet D. (2017), Adam Smith, Market and Social change: Then and Now. „Markets, Globalization \& Development Review" (MGDR) 2(1).

Bouchet D. (2018), Marketing, violence and social cohesion: First steps to a conceptual approach to the understanding of the normalising role of marketing. „Journal of Marketing Management”, vol. 34 (11-12): Violence, Markets and Marketing: 1048-1062.

Degaine A. (1993), Histoire du théatre en bande dessinée. Paris: Nizet, 3 place de la Sorbonne.

Fléouter C. (1977), Le gai ravage. „Le Monde” Paris, s. 1-15.

Goscinny R. (1963), La potachologie. Histoire naturelle du potache. (Dessins de Cabu). Paris: Denoël.

Goscinny R. (1965), Le potache est servi. (Dessins de Cabu). Paris: Denoël.

Goscinny R. (2014), Goscinny raconte les secrets d'Astérix. Paris: Le Cherche Midi.

Goscinny R. (2019), Entretien. Propos recueillis en août 1973 par Numa Sadoul [w:] N. Tellop (red.), Astérix le gaulois. La naissance d'un mythe, Paris: Les Cahiers de la BD, s. 36-41.

Groensteen T. (2017), 1833-2000: une brève histoire de la bande dessinée. „Le Débat” 3(3): 51-66. https://doi.org/10.3917/ deba.195.0051.

Gutwirth J. (2011), Être juif en Pologne. Mille ans d'histoire. Du Moyen âge à 1939. Paris: Albin Michel.

Lipovetsky G. (2003), La société d'hyperconsommation. „Le Débat” 124(mars-avril): 74-98.

Mnouchkine A. (1978), Molière. Pp. 244. France.

Morin E. (1975a), L’Esprit du temps. Tome I: Névrose. Paris: Grasset.

Morin E. (1975b), L'Esprit du temps. Tome II: Nécrose. Paris: Grasset.

Morin E. (1983), L'Esprit du temps. Edition augmentée. Paris: LGF, Le Livre de Poche, Collection Biblio Essais.

Ory P. (red.) (1987), Goscinny. La liberté d'en rire. Paris: Perrin.

Ory P. (red.) (2013), Dictionnaire des étrangers qui ont fait la France. Paris: Robert Laffont.

Rouvière N. (2008), Astérix ou la parodie des identités. Paris: Flammarion Collection Champs arts N. 763.

Tellop N. (2019), Qui sont les modèles d'Astérix? [w:] N. Tellop (red.), Astérix le gaulois. La naissance d'un mythe, Paris: Les Cahiers de la BD, s. 16-23.

Temine É. (1999), France, terre d'immigration. Paris: Gallimard (Collection Découvertes Numéro 380).

Vial É. (1999), Immigrés et étrangers [w:] F. Sirinelli i J.-P. Rioux, La France d'un siècle à l'autre. 1914-2000. Dictionnaire critique, Paris: Hachette, s. 642-651. 